\title{
MYCORRHIZATION IN BRYOPHYTE RICCIA DISCOLOR LEHM. ET. LINDENB.
}

\author{
WANKHEDE T.B. \\ Department of Botany, Shri Shivaji Science College, Amravati \\ E-mail: tusharwan@gmail.com
}

\begin{abstract}
:
Bryophyte Riccia discolor have lusty green thallus overlapping in dense patches, forming a rosettes commonly found in Melghat forest of Amravati District Maharashtra. Plant grow on moist soil or rocks in exposed situation dominantly during rainy seasons. Thalli found dioecious in green, one or twice forked and lobes oblong. Female plants larger than the male plants up to $15 \mathrm{~mm}$ long and up to $7 \mathrm{~mm}$ broad. Male thalli found smaller, $2-8 \mathrm{~mm}$ long and 2-5 $\mathrm{mm}$ broad with a groove that is narrow at apex and flat. Ventral surface bears simple and tuberculate rhizoids. As bryophytes are confined to specific regions due to their ecological indicator species various remarkable attributes pertains like soil microflora is prevailed. In present investigation, occurrence of arbuscular mycorrhizal (AM) fungal association was elaborated considering their pioneer role in succession. Various arbuscular mycorrhizal fungal spores reported from the soil around the thallus of this experimental small wonders of nature with probable symbiotic linkage of association.
\end{abstract}

Key words: Bryophyte, AM fungi, Symbiosis

\section{INTRODUCTION:}

Certain fungi are peculiar of a particular vegetation type or geographical area and sometimes act as indicator of the population in temperate, tropics or savannas region (Christensen, 1981). The microbial biomass in the soil is made up of bacteria, fungi, algae, protozoan, and nematodes contributing $25 \%$ of the total biomass on the earth. It is a complex mixture of living, dead, decomposing material and inorganic compounds (Gupta, 1998). Vesicular Arbuscular Mycorrhiza (VAM) fungi are naturally occurring fungal component of soil biota in most terrestrial ecosystem. These fungi are ubiquitous in distribution and unique as they are partly inside and partly outside the root. The vesicles, arbuscules and hyphae that are formed inside the host root does not encounter competition and antagonism from soil microorganisms to host rhizospheric soil conditions and host genotype (Manoharachary et al., 2002). The fossil evidences clearly indicates that the invasion of land by the early land plants like bryophytes clearly seems to have been facilitated by the origin of symbiotic association between the plants and mycorrhizal fungi at early Devonian period (Remy et al., 1994). Hence, fungal symbioses are one of the key attributes of present day land plants.

Although, liverworts do not have roots, but a similar organ of attachment like rhizoids are responsible for fixation and absorption of water or nutrients from soil. The cellular structures of association and the fungi involved with mycorrhiza like association is reported in Marchantia foliacea using scanning or transmission electron microscopy (SEM or TEM). Using molecular techniques, it was found that the pattern of DNA variation is seen in r-DNA sequences of $M$. foliacea endophytes was consistent with previous studies of glomeromycotan fungi (Russell and Bulman, 2005). On recent studies, Lingrone et al., (2007) strongly supports that the topology of liverwort phylogenies shows symbioses with glomeromycete fungi as a basal trait of liverworts that long predates Vesicular Arbuscular Mycorrhiza in other plants. 
Bidartondo and Duckett (2009) studied the conservative ecological and evolutionary patterns in liverworts with fungal symbioses and confirmed that simple thalloid liverworts associate with glomeromycete fungi in a way similar to most vascular plants.

Zhang and Guo (2007) recorded AM fungal structures in mosses stem and leaf tissues but not in rhizoids of Leucobryum glaucum, $L$. javense, Trichostomum crispulum etc. The VA mycorrhizal spores like Glomus, Acaulospora and Gigaspora were observed among these mosses. Pressel et al., (2010) provided new insight in the twenty first century about fungal symbioses in bryophytes. Isolation, re-synthesis and sequencing experiments have shed considerable light on functional relationship of bryophyte as host and fungi as symbionts. Here Treubia and Haplomitrium were currently considered as bryophytes of very long history in the land plant tree of life showing presence of Glomus i.e. mycorrhizal endophytes. Liepina, (2012) studied 43 bryophyte species and reported Glomalian fungi in most of liverworts and hornworts but less in mosses.

\section{MATERIAL AND METHODS:}

Soil attached to plant thallus Riccia discolour occurred in rhizosphere or mycorrhizosphere was collected, dried and preserved in zip lock polythene bags to avoid contact with air nitrogen. VAM spores were isolated from the soils closely attached to gametophytic thalli of bryophytes collected from different habitats. Isolation of VAM fungal spores from soil was done following the wet sieving and decanting method of Gerdemann and Nicolson (1963).

Estimation of VAM fungal spore was done using filter paper for intact spore collection and mounted in polyvinyl alcohol lacto-glycerol (PVLG) on glass slides. Melzer's reagent was used while mounting intact or crushed spores in PVLG for morphology based diagnoses (Koske and Tessier, 1983).
Structures produced by Glomeromycotan fungi are usually hidden by natural pigments and cell contents. Hence clearing procedure for removing these plant tissues using chemical agents was done. All the thalli with rhizoids were cleared using $\mathrm{NaOH}$ and $\mathrm{KOH}$ treatment. All the material was stained by Trypan Blue for determining possible VAM colonization (Phillips and Hayman, 1970). Identification of VAM spores were done by using manual of Schenck and Perez (1990) The murographs sheets were used for the taxonomic identification occurrence of spores, size and shape, colour, subtending hypha, wall layers.

\section{RESULT AND DISCUSSION:}

The AM fungi spores diversity has been observed among soil isolated form Riccia discolour thallus showing two species of Acaulospora, twos species of Gigaspora, six species of Glomus and two species of Scutellospora dominantly. The characteristics are as follows.

1. Acaulospora delicata Walker, Pfeiffer and Bloss (Plate No. 1 A)

Spores borne singly in the soil, hyaline to pale yellowish cream; sparking nature of the spore content; shape globose to subglobose or rarely ovoid to abovoid; spore size ranges from 80 - 125 x 80 - $110 \mu \mathrm{m}$. sporiferous saccule usually broader than long. Spore wall generally four walled, but appears two under light microscope, outer two and inner two walls, the outer wall thin, hyaline, evanescent $1 \mu \mathrm{m}$ thick, followed by adjacent pale yellow, laminated 3.5-5 thick wall. Soil particles often attached to the outer wall. The inner walls thin, hyaline, membranous and 0.5 to $1 \mu \mathrm{m}$ thick, covered by minute granules.

2. Acaulospora denticulata Sieverding and Toro (Plate No. 1 B)

Spores yellow brown to dark brown, globose to sub-globose, spores formed laterally on sporiferous saccule, 80-160 $\mu \mathrm{m}$ in diameter produced singly in soil. Spore walls generally four 
walled, in two separable groups. The outermost layer found yellow brown of $0.5 \mu \mathrm{m}$ thick with inseparable polygonal segments. The inner wall group composed of three hyaline layers, each one 0.5 to $1.5 \mu \mathrm{m}$ thick, and walls may separate or attached to the wall four.

3. Gigaspora albida Schenck and Smith (Plate No. 1 C)

Spores formed singly in the soil, colour dull white with a light greenish yellow, spherical 143-350 $\mu \mathrm{m}$ diameter. Spore walls continuous, 4-12 $\mu \mathrm{m}$ thick with one to six layers. Layer one generally smooth and 1-2 $\mu \mathrm{m}$ thick. Layers two to six found laminated. Germ tube produced directly through the spore wall near the bulbous suspensor separating it from the spore contents. Hyaline to yellow, 24-36 $\mu \mathrm{m}$ diameter attached to septate hypha with fine hyphal branches.

4. Gigaspora gigantea (Nicolson and Gerdemann) Gerdemann and Trappe (Plate No. 1D)

Zygospores formed singly in soil, colour when mature bright yellow with greenish tings, spherical, ellipsoidal and cylindrical or irregular $183-500$ x $291-812 \mu \mathrm{m}$ in diameter. Spore wall with thin outer wall tightly covering a thick walled continuous endospore. Endospore wall found 2.5-7.5 $\mu \mathrm{m}$ thick. A bulbous suspensor 41-51 $\mu \mathrm{m}$ diameter with a slender hypha extending from the suspensor to the base of the spore and germ tube produced directly through the spore wall in the base region.

5. Glomus aggregatum Schenck and Smith emend. Koske (Plate No. 1 E)

Spores formed in sporocarps, 200-1400 $\mu \mathrm{m}$ in diameter, loosely aggregated spores lacking a peridium.

Spores: Spores produced in sporocarps with 20$210 \mu \mathrm{m}$ in diameter. Colour pale yellow to yellow brown, subtending hyphae straight, constricted, swollen or irregular up to $12 \mu \mathrm{m}$ wide at the spore base. Spore wall composed of three layers, laminated 1-3 (-5) $\mu \mathrm{m}$ thick and often absent in mature spores. However, layer two found semi flexible, hyaline with 0.5-2 $\mu \mathrm{m}$ thickness. Layer three found laminated, smooth, yellowish brown with 2-4.5 $\mu \mathrm{m}$ in thickness. The subtending hyphae yellowish brown straight or curved, cylindrical to funnel shaped $6.4-14.3(-21.6) \mu \mathrm{m}$ wide at the spore base.

6. Glomus albidum Walker and Rhodes (Plate No. 1F)

Spores borne singly in the soil on coenocytic hyphae. Mature spores 95-168 x 95-168 $\mu \mathrm{m}$ in diameter or may vary, shape found globose to subglobose, occasionally ovoid or irregular. Spore wall continuous with hyphal wall with two layers. Layer one consists of an outer hyaline wall of 0.5$2 \mu \mathrm{m}$ in thickness and the inner sub equal finely laminated wall with yellow colour having 0.5-2 $\mu \mathrm{m}$ thickness. Spore contents showed crowded oil droplets, usually becoming angular from mutual pressure to give a reticulate appearance.

\section{Funneliformis constrictum (Trappe) Walker and Schüßler (Plate No. 1 G) Old}

\section{Name: Glomus constrictum (Trappe)}

Spores formed singly or in loose clusters in the soil, shape globose to subglobose, colour dark brown to black, shiny smooth with 150-330 $\mu \mathrm{m}$ in diameter. Spore walls 7-15 $\mu \mathrm{m}$ thick, composed of two layers, straight with a short funnel shaped projection. Attached hyphae found straight or recurved at the point of attachment with dark brown walls, 3-5 $\mu \mathrm{m}$ thick. Just beyond the point of attachment, the hypha constricted to $10-22 \mu \mathrm{m}$ diameter. Just beyond the constriction, the hypha inflated to 15-30 $\mu \mathrm{m}$ diameter with yellow brown walls of 2-3 $\mu \mathrm{m}$ thickness. However, layer one found hyaline to pale yellow 0.8-2.5 (-8.5) $\mu \mathrm{m}$ in thickness. The layer two found laminate smooth brownish, orange to dark brown in colour with 7.5-12 $\mu \mathrm{m}$ in thickness. Most juvenile spores with one layer.

8. Rhizophagus diaphanum (Morton and Walker) Walker and Schüßler 
(Plate No. $1 \mathrm{H})$ Old Name: Glomus diaphanum Morton and Walker

Spores produced singly or in loose clusters in soil, hyaline, globose to subglobose 39-100 (-121) $\mu \mathrm{m}$ in diameter and sporocarps unknown. Spore wall composed of two layers. The first layer found laminated with 2-4.4 (-6.5) $\mu \mathrm{m}$ in thickness. The second layer noticeably membranous 0.2- 0.8 (1.3) $\mu \mathrm{m}$ in thickness, extended 5-12 $\mu \mathrm{m}$ into the subtending hypha and forms a septum enclosing the spore contents. Spore wall hyaline and contain one to many oil globules. Subtending hypha 5.4-11 $\mu \mathrm{m}$ in diameter at the spore base and hyphal wall 1.4-3 (-3.7) $\mu \mathrm{m}$ in thickness.

9. Claroideoglomus etunicatum (Becker and Gerdemann) Walker and Schüßler

(Plate No. 2 A) Old Name: Glomus etunicatum (Becker and Gerdemann)

Spores formed singly in soil, colour light brown, globose to subglobose, size 68-162 $\mu \mathrm{m}$ in diameter, smooth or roughened from decomposition of the outer wall and adherent debris. Spore wall composed of two layers with 4$13 \mu \mathrm{m}$ thick. The ephemeral hyaline outer wall up to $5 \mu \mathrm{m}$ in thickness and persistent yellow to brown laminate inner wall 2-8 $\mu \mathrm{m}$ in thickness and spore contents separated from attached hypha by a thin curved septum.

10. Funneliformis geosporum (Nicolson and Gerdemann) Walker and Schüßler

(Plate No. 2 B) Old Name: Glomus geosporum Nicolson and Gerdemann

Spores formed singly in soil, ellipsoidal, light to dark brown, 110-290 $\mu \mathrm{m}$ in diameter. Spores generally with straight to recurved funnel shaped subtending hyphae of $10-24 \mu \mathrm{m}$ in diameter. Spore wall composed 3 layers, 4-8 $\mu \mathrm{m}$ thick. The layer one found tightly adherent and found less than $1 \mu \mathrm{m}$ in thickness. The second layer generally yellow brown to red brown, laminated with 3-16 $\mu \mathrm{m}$ in thickness. The third layer found yellow-brown, less than $1 \mu \mathrm{m}$ thickness, membranous, forming a septum separating the spore contents from the subtending hypha. Spore contents uniform sized droplets granular in appearance with maturity, separated by a septum that protrudes slightly into subtending hypha.

11. Scutellospora auriglobosa (Hall) Walker and Sanders (Plate No. 2 C)

Spores generally ectocarpic, globose or rarely polymorphic, 200-420 (-520) x 130-420 (-520) $\mu \mathrm{m}$ in diameter, colour pale yellow, brown transparent and shining. Moribund spore found brown in colour. Spore wall generally, 2 to 4 layered, outer wall coloured with 6-16 $\mu \mathrm{m}$ in thickness. The inner walls found $0.1 \mu \mathrm{m}$ thick and colourless to yellow. Spores formed on a bulbous suspensor 40-70 $\mu \mathrm{m}$ diameter. Walls of the subtending hypha found 3-10 $\mu \mathrm{m}$ thick, yellow to light brown.

12. Scutellospora pellucida (Nicolson and Schenck) Walker and Sanders (Plate No. 2 D)

Spores formed singly in the soil, borne terminally on a bulbous suspensor like cells, glinting with oil droplets, hyaline to pale gray coloured, globose, ellipsoid, or irregular and size 58-183 x 58-241 $\mu \mathrm{m}$ in diameter. Spore wall composed of six layers. The outer layer one found smooth, brittle, hyaline, unit wall 1-2 $\mu \mathrm{m}$ in thickness. While layer two found hyaline, laminated and 2-7 $\mu \mathrm{m}$ thick. The third layer generally hyaline membranous wall of $1 \mu \mathrm{m}$ thick while wall four 1 $2 \mu \mathrm{m}$ thick followed by fifth wall of $5-8 \mu \mathrm{m}$ thick and wall six found hyaline, single amorphous wall of $2-5 \mu \mathrm{m}$ thickness.

Rhizoidal colonization of vesicles: Although the occurrence of VAM fungal spores were a normal phenomenon from soil based isolation but their rhizoidal infections or root infections among the host plant determines a key attribute for host and fungus association. In this exploration rhizoidal infections of VAM fungi seen for the authentic association between host plant and the fungus. The thalli of Riccia discolor under cytological study where rhizoids were stained by Tryphan blue or acid Fuchsin stain show 
rhizoidal infection of hyphae and some vesicle like structure in rhizoidal colonization of VAM fungi (Plate: $2 \mathrm{G}, \mathrm{H}$ )

\section{Spores in spore syndrome}

The presences of AM fungal spores inside the dead spores of other VAM fungal species were reported among few spores (Plate: 22 E,F). Various studies have reported the presence of AM fungal spores inside the dead spores of other VAM fungal species (Koske et al., 1986). This suggests that spores of AM fungi acts as a microhabitat when they are dead, apart from their normal role as propagules. It also suggests the ability of different AM fungal species to sporulate in close proximity to each other.

In the present investigations, it was observed that rhizospheric or mycorrhizospheric soil of collected bryophytes harbor different types of VAM fungal species. Here plant Riccia liverwort s of Melghat region found true mycotrophic on terricolous substrate. The species like Acaulospora, Gigaspora found less common but, the Glomus species found dominant in all the collected sample and widely distributed among all the locations of Melghat forest. The species like Glomus aggregatum, Glomus albidum Funneliformis constrictum, Rhizophagus diaphanum, Claroideoglomus etunicatum, Funneliformis geosporum, found common in almost soil samples. In unique findings, the species of Scutellispora like Scutellospora auriglobosa, Scutellispora pellucida, found in liverworts Vyas et al., (2007). In present investigations, the author found that among glomelian fungi, Glomus sp. found dominated as compare to Acaulospora sp., Scutellispora sp. and Gigaspora sp. Douds and Millner (1999) suggested that this might be due to the local environments that provide conducive conditions for the occurrence of Glomus sp. and these fungal species represents as a significant members of the vegetation community. Liepina (2012) reaffirmed the occurrence of VAM fungal structures in 29 families of bryophytes in which most of them found symbiotic in association. This is consistent with our idea that mycorrhizal symbiosis occurs among bryophytes.

\section{CONCLUSION:}

Being as a precursor on the land, the bryophytes considered as a most primitive, early land plants on the earth. In present investigation, the bryophytic plant Riccia discolor found associated with soil borne AM fungi. It can be affirmed that the process of mycorrhization found silent partner along with the evolutionary aspects among early land plants.

\section{REFERENCES:}

Bidartondo, M.I. and Duckett, J.G. (2009) A glimpses of conservative ecological and evolutionary patterns in liverwort fungal symbioses. Proceedings of the Royal Society Bulletin. 277: 485-492

Christensen, M. (1981) Species diversity and dominance in fungal communities. In: Wicklow, D.T. and Caroll, G.C. (Eds.), The Fungal Community. Marcel Dekker, New York: 201-232.

Douds, D.D. and Millner, P.D. (1999) Biodiversity of arbuscular mycorrhizal fungi in agro ecosystems, Agriculture Ecosystems and Environment 74: 77-93.

Gerdemann, J.W. and Nicolson, T.H. (1963) Spores of mycorrhiza endogone sp. extracted from soil by wet sieving and decanting, Transaction of the British Mycological Society 46: 235-244.

Gupta, V.V. (1998) The living soil: Soil microorganisms and their role in soil processes. Proc. 9th Australian cotton conf, Aug. 12-14, 1998, Broadbeach, Queensland, Australia : 43-48.

Koske and Tessier (1983) A convenient permanent slide mounting medium Mycol. Soc.Am. Newsl. 34 : 59-66.

Koske, R.E., Gemma H.N., Gema P.D., Olexia (1986) Glomus micro-aggregatum, a 
new species in the endogonaceae. Mycotaxon. 26: 125-132.

Liepina, L. (2012) Occurrence of fungal structures in bryophytes of the boreo-nemoral zone. Environmental and Experimental Biology 10 : 35-40.

Lingrone, R., Carafa, A, Lumini, E., Bianciotto, V., Bontante, P., Ducket G. (2007). Glomeromycotean association in liverworts : a molecular, cellular and taxonomic analysis. Am. J. Bot. 94: 1756-1777.

Manoharachary, C., Kunwar, I.K. and Mukherji, K.G. (2002) AM fungi Identification, Taxonomic Criteria, Classification, Controversies and Terminolgy. "Techniques in Mycorrhizal Studies" In; K.G. Mukherji, Kluwer Academic Publisher: 249-272.

Phillips, J.M. and Hayman, D.S. (1970) Improved procedures for cleaning roots and staining parasitic and Vesicular Arbuscular Mycorrhizal fungi for rapid assessment of infection, Transaction of the British Mycological Society, 55: 158161.
Pressel, S., Bidartondo, M.I., Lingrone, R. and Ducket, J.G. (2010) Fungal Symbiosis in Bryophytes : New Insights in the Twenty First Century, Phytotaxa. 9: 238-253.

Remy, W., Tayler, Karp, H. (1994) Four hundred million years old vesicular arbuscular mycorrhizae, Proceedings of National Academy of Sciences USA 91: 11841 11843.

Russell, J. and Bulman, S. (2005) The liverwort Marchantia foliaceae forms a special symbiosis with VAM fungi in the genus Glomus, New Phytologist 165: 567-579.

Schenck, N.C. and Perez, Y. (1990) A unique code for each species of VA mycorrhizal fungi. Mycologia. 52: 256-260.

Vyas, D., Dubey, A., Soni, A., Mishra, M., Singh, P. K. (2007) Arbuscular mycorrhizal fungi in early land plants. Mycorrhiza News. 19 (2): 22-24.

Zhang, Y. and Guo, L.D. (2007) Arbuscular mycorrhizal structure and fungi associated with mosses. Mycorrhiza. 17: 319-325. 
PLATE - 1

Morpho-diversity of VAM fungal spores

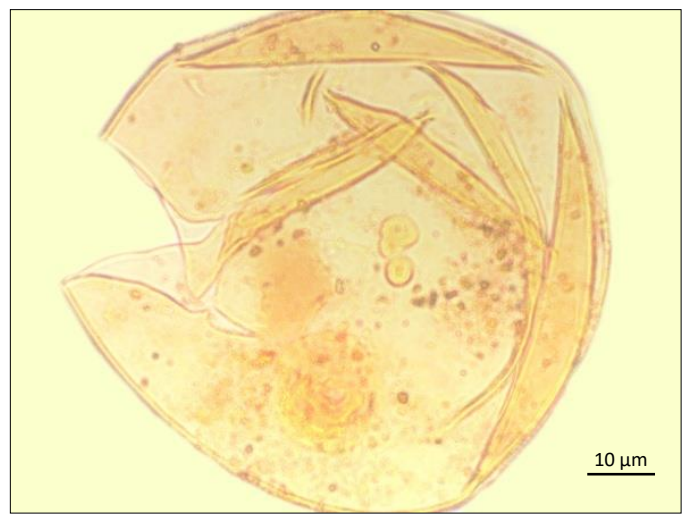

A. Acaulospora delicata $(40 \times 10)$

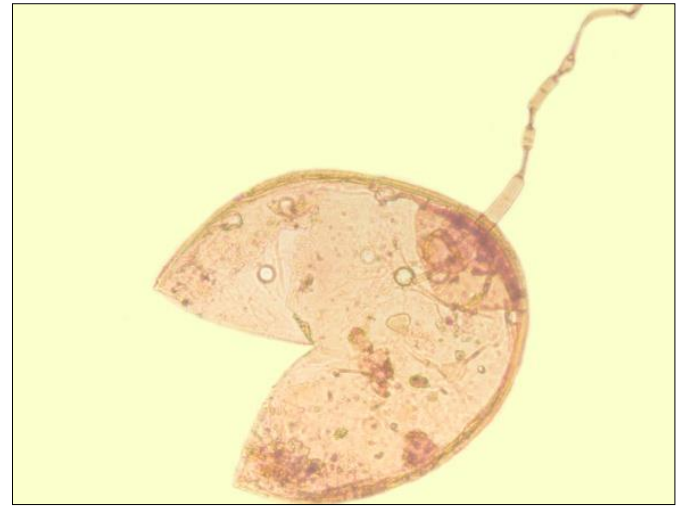

C. Gigaspora albida (40x10)

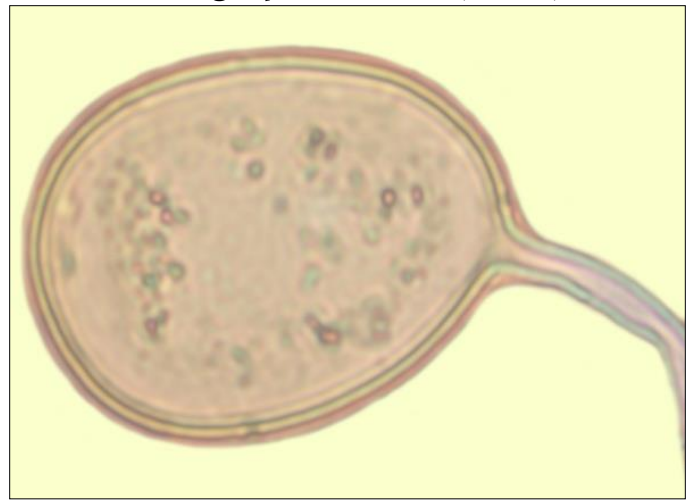

E. Glomus aggregatum (100x10)

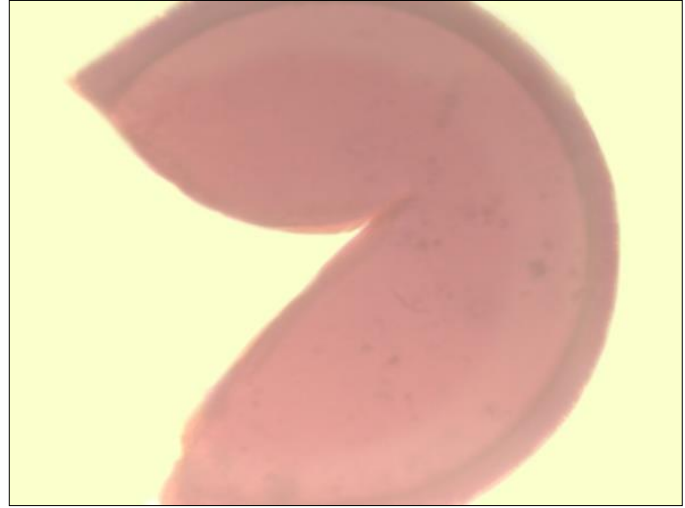

G. Funneliformis constrictum $(40 \times 10$

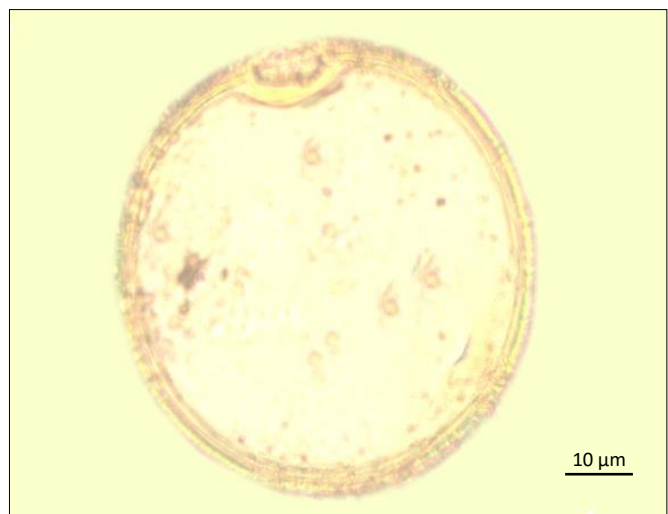

B. Acaulospora denticulata (40x10)

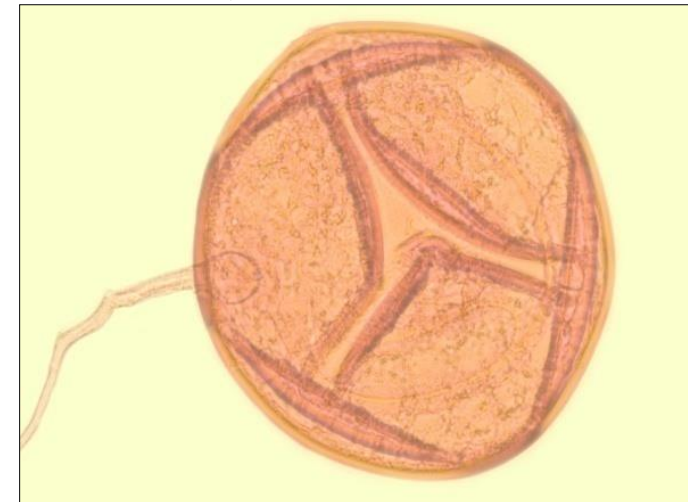

D. Gigaspora gigantea (40x10)

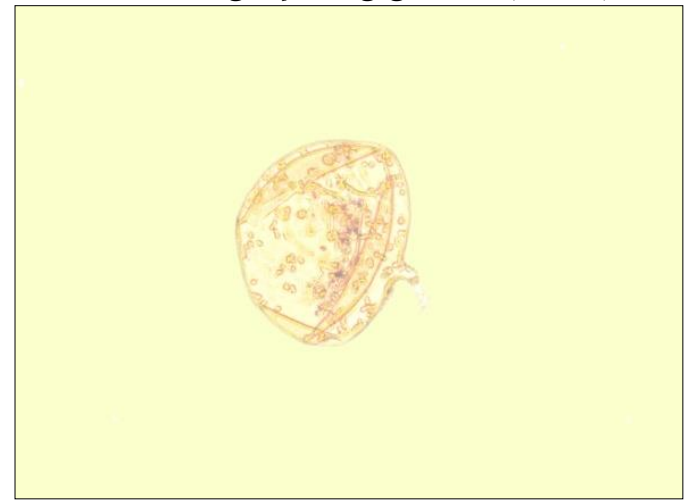

F. Glomus albida (10x10)

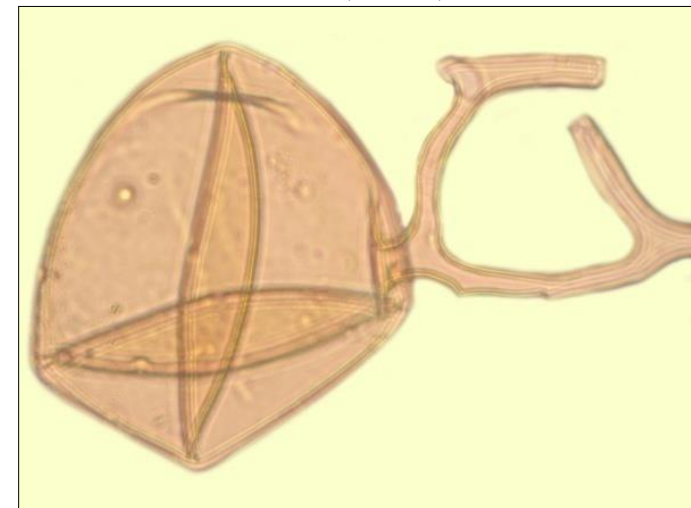

H. Rhizophagus diaphanum (40x10) 


\section{PLATE - 2}

Morpho-diversity of VAM fungal spores

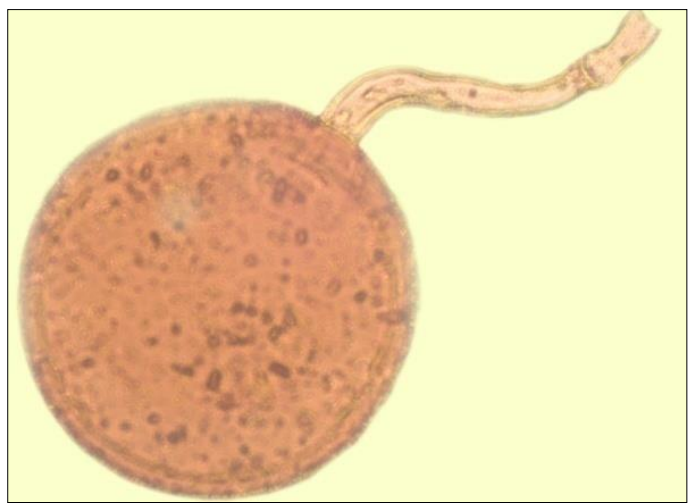

A. Claroideoglomus etunicatum (40x10)

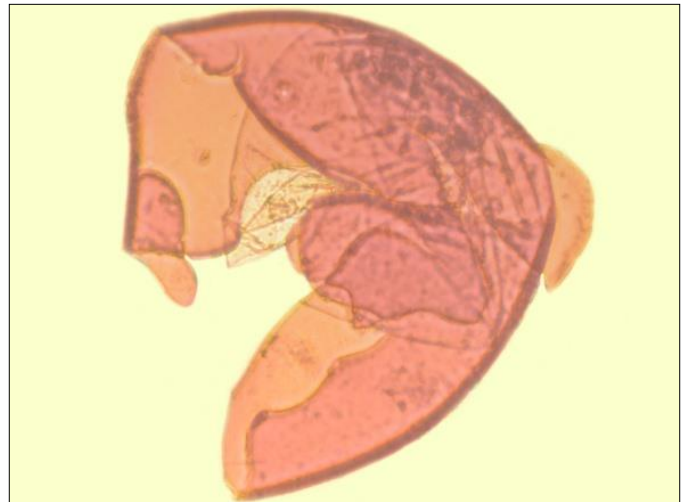

C. Scutellospora auriglobosa (40x10)

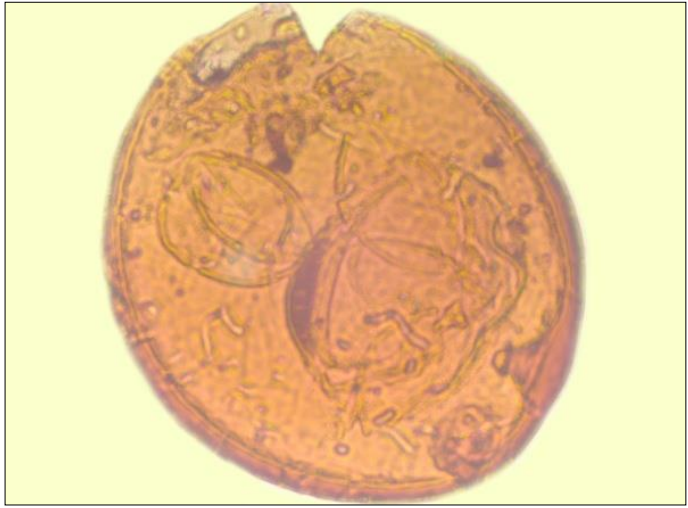

E. Spores in spore syndrome $(40 \times 10)$

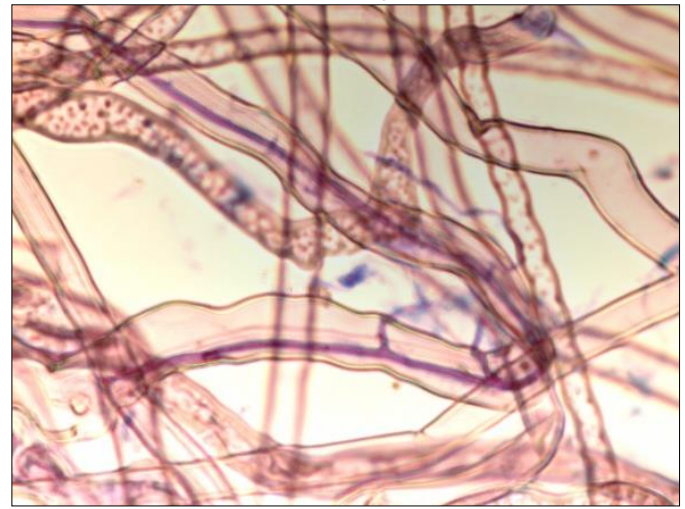

G. Rhizoidal infection (40x10)

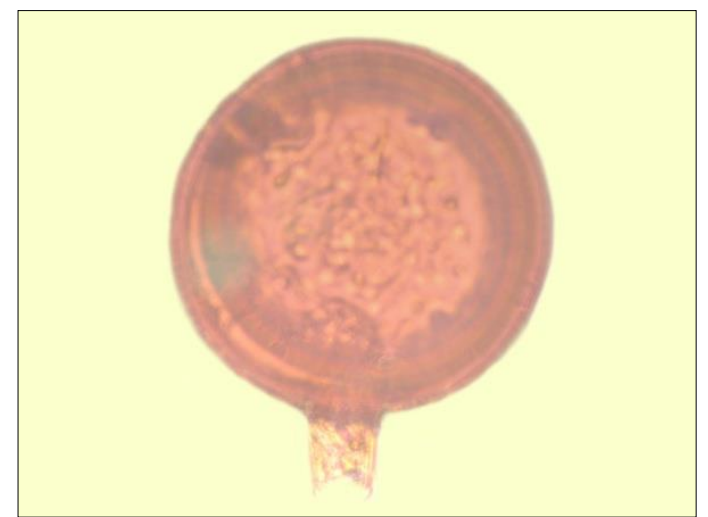

B. Funneliformis geosporum (40x10)

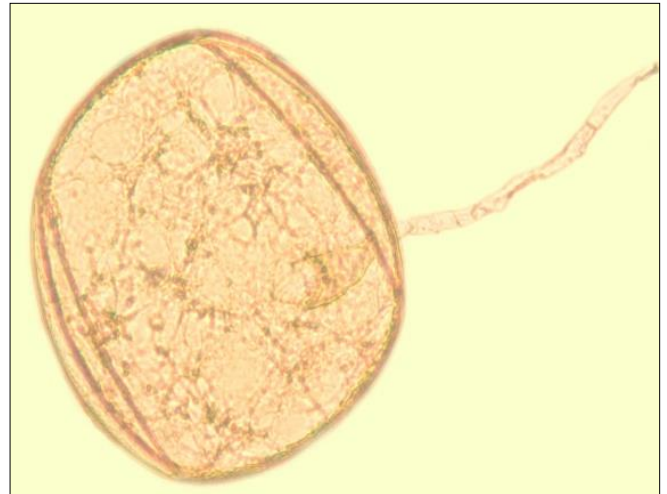

D. Scutellospora pellucida (40x10)

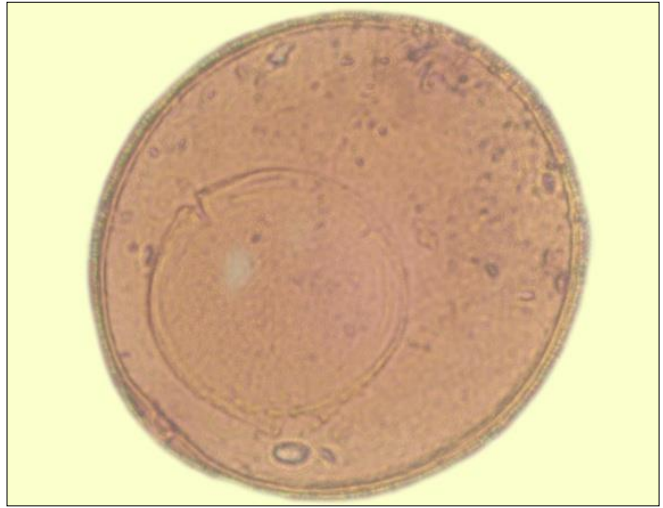

F. Spores in spore syndrome $(40 \times 10)$

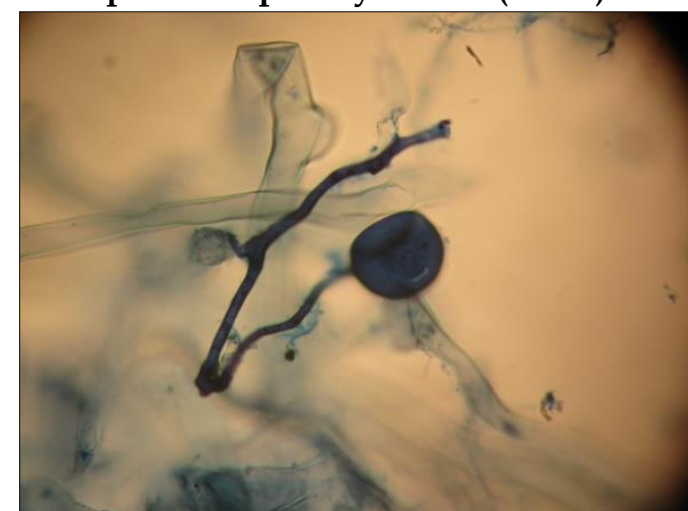

H. Vesicle like structure $(40 \times 10)$ 